\title{
Sperm motility and velocities of Characiformes fishes in different times post-activation
}

\section{Motilidade e velocidades espermáticas de peixes Characiformes em diferentes tempos pós ativação}

\author{
Mônica Aline Parente Melo-Maciel ${ }^{1 *}$; José Ferreira Nunes ${ }^{2}$; \\ João Paulo Silva Pinheiro'; Larissa Teixeira Nunes ${ }^{1}$; Romulo Roberto Ribeiro \\ Pinheiro $^{3}$; Júlia Trugilio Lopes ${ }^{1}$; Carminda Sandra Brito Salmito-Vanderley ${ }^{4}$
}

\begin{abstract}
The objective of the current study was to observe the performance kinetics (motilities and velocities) of the spermatozoa from Prochilodus brevis (curimatã), Colossoma macropomum (tambaqui) and Piaractus brachypomus (pirapitinga) species in different times post-activation. The sperm of $P$. brevis, C. macropomum and P. brachypomus species were collected after hormonal induction with carp pituitary extract. The samples with not contamination with water, urine or feces had motility subjective, morphology, osmolality and concentration analyzed. The samples selected were analyzed with Sperm Class Analyzer. Spermatozoa motility and velocities were captured at 10, 30, 60 and 120 s postactivation. No significant differences in total motility of $P$. brevis spermatozoa were observed between $10 \mathrm{~s}$ and $30 \mathrm{~s}$ post-activation. However, significant reduction was observed in $60 \mathrm{~s}$. This reduction was more accentuated after $120 \mathrm{~s}$. The same pattern of spermatozoa motility decline happened for $C$. macropomum and P. brachypomus. Velocities also followed the same pattern for the three species. There was significant reduction in velocities after $30 \mathrm{~s}$; this reduction was more significant after $60 \mathrm{~s}$. There was no significance difference between $60 \mathrm{~s}$ and $120 \mathrm{~s}$ post-activation. Sperm of $C$. macropomum and $P$. brachypomus show satisfactory sperm quality up to $60 \mathrm{~s}$ after activation. On the other hand, sperm of $P$. brevis up to $120 \mathrm{~s}$ after activation. These findings show that the rate of sperm motility in different times post activation is change for each species tested.
\end{abstract}

Key words: Colossoma macropomum, Piaractus brachypomus, Prochilodus brevis, sperm class analyzer

\section{Resumo}

O objetivo do presente trabalho foi investigar o desempenho cinético (motilidade e velocidades espermáticas) de Prochilodus brevis (curimatã), Colossoma macropomum (tambaqui) e Piaractus brachypomus (pirapitinga) em diferentes tempos pós ativação. O sêmen de P. brevis, C. macropomum e P. brachypomus foi coletado após indução hormonal com extrato hipofisário de carpa. As amostras não contaminadas com sangue, fezes ou urina tiveram motilidade subjetiva, morfologia, osmolaridade e concentração analisadas. As amostras selecionadas foram analisadas com o Sperm Class Analyzer.

\footnotetext{
1 Discentes, Curso de Doutorado do Programa de Pós-Graduação em Ciências Veterinárias, Universidade Estadual do Ceará, UECE, Fortaleza, CE, Brasil. E-mail: monicaaline3@hotmail.com; joaopaulospinheiro@yahoo.com.br; larissatn.br@hotmail. com; juliatrugilio@gmail.com

2 Prof. Dr., Faculdade de Veterinária, UECE, Fortaleza, CE, Brasil. E-mail: ferreiranunes@hotmail.com

3 Discente, Curso de Graduação em Ciências Biológicas, UECE, Fortaleza, CE, Brasil. E-mail: romuloroberto_bio@hotmail.com

4 Prof $^{\text {a }}$ Dra $^{\text {a }}$, Curso de Ciências Biológicas, UECE, Fortaleza, CE, Brasil. E-mail: sandra.salmito@uece.br

* Author for correspondence
} 
A motilidade e velocidade dos espermatozoides foram mensuradas a 10, 30, 60 e $120 \mathrm{~s}$ pós ativação. Nenhuma diferença significativa na motilidade total do sêmen de P. brevis foi observada entre $10 \mathrm{~s}$ e $30 \mathrm{~s}$ pós ativação. No entanto, uma redução significativa foi observada aos $60 \mathrm{~s}$. Essa redução foi mais acentuada após $120 \mathrm{~s}$. O mesmo padrão de declínio da motilidade espermática ocorreu para $C$. macropoтum e $P$. brachypomus. As velocidades espermáticas seguiram o mesmo padrão para as três espécies. Houve redução significativa nas velocidades após $30 \mathrm{~s}$; essa redução foi mais significativa após $60 \mathrm{~s}$. Não houve diferença significativa entre $60 \mathrm{~s}$ e $120 \mathrm{~s}$ pós ativação. Os espermatozoides de $C$. macropomum e $P$. brachypomus apresentam satisfatotia qualidade espermática até $60 \mathrm{~s}$ pós ativação. Por outro lado, os espermatozoides de $P$. brevis apresentam satisfatória qualidade espermática até 120 s pós ativação. Esses achados mostram que a taxa de motilidade espermática em diferentes tempos pós ativação muda para cada espécie testada.

Palavras-chave: Colossoma macropomum, Piaractus brachypomus, Prochilodus brevis, sperm class analyzer

The Prochilodus brevis (curimatã), Colossoma macropomum (tambaqui) and Piaractus brachypomus (pirapitinga) are Characiformes fish and are native to South America. Characiformes have commercial importance as ornamental species, food in fisheries, aquaculture, or sport fishing (GODINHO; VIVEIROS, 2011; GURGEL et al., 2012; RAMIREZ-MERLANO et al., 2011).

Prior to spermiation, fish sperm are stored in an immotile state in the testes, and the motility of sperm is associated with their sensitivity to osmolality and the ion concentration in the media where the sperm is released (ALAVI; COSSON, 2006). Sperm motility in freshwater fish is best initiated with media that is hypo-osmotic relative to seminal fluid (COSSON, 2010). After initiation of motility, spermatozoa become motile and metabolically active briefly. Thus it is important the knowledge of spermatozoa motility during the period that the sperm is active for each species worked (CARNEIRO, 2007).

Objective analyses can provide precise and accurate information on spermatozoa motility (NASCIMENTO et al., 2010), however, there are few data reported for $P$. brevis and P. brachypomus. Furthermore, there are no reports on spermatozoa motility in different periods post-activation for $C$. macropomum, P. brevis, and P. brachypomus.

The objective of this study was to observe the performance kinetics (motilities and velocities) of the spermatozoa from C. macropomum, P. brevis and $P$. brachypomus species at different time postactivation of motility.

This work was approved by the ethics committee for animal use with the following protocol numbers 11518754-5/74 (C. macropomum), 1278971-1 (P. brachypomus) and 12776936-6 (P. brevis). C. macropomum and $P$. brachypomus males were selected from tanks at the Departamento Nacional de Obras Contra as Secas (DNOCS) in the city of Pentecoste, state of Ceará, Brazil, and P. brevis males were selected from tanks at the Laboratório de Biotecnologia da Reprodução de Peixes (LBRP) in the city of Fortaleza, state of Ceará, Brazil. The weight of the C. macropomum was $5.88 \pm 1.03 \mathrm{~kg}$; the $P$. brachypomus was $3.78 \pm 0.9 \mathrm{~kg}$ and the $P$. brevis was $0.56 \pm 0.1 \mathrm{~kg}$.

Males with detectable sperm under soft abdominal pressure were given a single treatment via the intracelomatic route $\left(2 \mathrm{mg} \mathrm{kg}^{-1}\right.$ of body weight) of carp pituitary extract. After 448 hoursdegree, animals were anesthetized using a clove oilbased solution (1:10:10000; eugenol:alcohol:water). The urogenital papilla was carefully dried, and sperm were hand stripped directly into graduated tubes. Sperm collection was completed at room temperature $\left(28 \pm 1^{\circ} \mathrm{C}\right)$, and soon after collection, the animals were returned to the tank. Tubes containing sperm were placed in crushed ice $\left(5^{\circ} \mathrm{C}\right)$. Contamination of sperm with water, urine or feces was carefully avoided. 
Immediately after collection, each semen sample was placed on a glass slide and observed under a light microscope at $100 \mathrm{X}$ magnification. Spermatozoa motility (auto-activation) observed was attributed to urine or water contamination and the sample was discarded. Motility was subjectively estimated as the percentage of motile spermatozoa. Selected samples from C. macropomum $(\mathrm{n}=17)$, P. brachypomus $(\mathrm{n}=19)$ and $P$. brevis $(\mathrm{n}=18)$ were activated with an activation solution (tank water) at a final dilution ratio of 1:50 (sperm: activation solution; v: v). Samples with at least $80 \%$ motile spermatozoa were used in this study.

The analyzed parameters in the sperm samples were volume $(\mathrm{mL})$, directly observed in the graduated tubes; osmolality of seminal plasma $\left(\mathrm{mOsm} \mathrm{kg}^{-1}\right)$, measured with a Peltier digital osmometer (Roebling, Germany); concentration (number of spermatozoa per $\mathrm{mL}$ ) by diluting samples in 4\% formol-citrate solution and analyzing in a Neubauer hemocytometer chamber.

The spermatic kinetic parameters analyzed were: rate of motility $(\%)$, curvilinear velocity (VCL, $\mu \mathrm{m}$ $\mathrm{s}^{-1}$ ), straight line velocity (VSL, $\mu \mathrm{m} \mathrm{s}^{-1}$ ) and average path velocity (VAP, $\mu \mathrm{m} \mathrm{s}^{-1}$ ). These parameters were captured until the sperm submit at least 30\% motility, observed at $10 \mathrm{~s}, 30 \mathrm{~s}, 60 \mathrm{~s}, 120 \mathrm{~s}$ postactivation. The analyze occurred after addition activation solution using $2 \mathrm{~mL}$ of each sperm sample diluted in $100 \mathrm{~mL}$ of $50 \mathrm{mM} \mathrm{NaCl}(100 \mathrm{mOsm} \mathrm{kg}$ ) onto a Makler chamber and evaluated under light microscopy (400x) with the Sperm Class Analyzer (SCA; Microptics, Spain). Spermatozoa were considered immotile when the velocity was $<10$ $\mu \mathrm{m} \mathrm{s}^{-1}$.

All data were expressed as the mean \pm SD. Spermatozoa motility (rates and velocities) were tested for normal distribution. When the data did not fit the normal distribution, an arcsine transformation was performed. All data for spermatozoa motility (rates and velocities) were tested for significant differences using an ANOVA, followed by the Tukey's test when necessary. All data were evaluated using the statistical software SAS v.8 (2000). The level of significance for all statistical tests was $\mathrm{P}<$ 0.05 .

Semen characteristics of $C$. macropomum, $P$. brachypomus and $P$. brevis species after induction with carp pituitary extract were respectively: a) volume $(\mathrm{mL}): 3.74 \pm 1.14,3.90 \pm 1.60$ and $1.78 \pm$ 0.62 ; b) concentration $\left(10^{9} \mathrm{~mL}^{-1}\right): 5.72 \pm 2.82,4.13$ \pm 2.12 and $30.82 \pm 6.83$; c) osmolality $\left(\mathrm{mOsm} \mathrm{kg}^{-1}\right)$ : $298.00 \pm 48.50,273.00 \pm 52.80$ and $292.17 \pm 10.81$; d) motility subjective (\%): $92.10 \pm 6.15,90.00 \pm$ 12.00 and $95.61 \pm 3.07$.

No significant differences in the motility of the sperm of $P$. brevis were observed between 10 $\mathrm{s}$ and $30 \mathrm{~s}$ post-activation. However, a significant reduction was observed in $60 \mathrm{~s}$. This reduction was more accentuated after $120 \mathrm{~s}$. The same pattern of sperm motility decline happened in C. macropomum and $P$. brachypomus. In these species, total motility at $10 \mathrm{~s}$ was similar to $30 \mathrm{~s}$. After $60 \mathrm{~s}$, a decrease in sperm motility $(\mathrm{p}<0.05)$ in the $C$. macropomum and $P$. brachypomus species was observed, and an important decline also occurred at $120 \mathrm{~s}$ (Table 1).

This is the first work that has evaluated spermatozoa motility at different times postactivation for P. brevis, C. macropomum and $P$. brachypomus species. Moreover, for $P$. brevis and $P$. brachypomus, no previous reports have that evaluated individually the sperm of each male using an automatized analyzer. 
Table 1. Percentage of spermatozoa motility at $10 \mathrm{~s}, 30 \mathrm{~s}, 60 \mathrm{~s}, 120 \mathrm{~s}$ post activation of $C$. macropomum (n $=17), P$. brachypomus $(\mathrm{n}=19)$ and P. brevis $(\mathrm{n}=18)$ species. Different letters in columns are significantly different at $\mathrm{p}<0.05$.

\begin{tabular}{cccc}
\hline Times post activation & C. macropomum & P. brachypomus & P. brevis \\
\hline $10 \mathrm{~s}$ & $84,77 \pm 4,11^{\mathrm{a}}$ & $82,40 \pm 3,63^{\mathrm{a}}$ & $96,17 \pm 1,09^{\mathrm{a}}$ \\
$30 \mathrm{~s}$ & $80,43 \pm 3,68^{\mathrm{a}}$ & $70,69 \pm 4,75^{\mathrm{a}}$ & $94,40 \pm 1,25^{\mathrm{a}}$ \\
$60 \mathrm{~s}$ & $35,74 \pm 3,42^{\mathrm{b}}$ & $33,68 \pm 3,37^{\mathrm{b}}$ & $77,91 \pm 3,67^{\mathrm{b}}$ \\
$120 \mathrm{~s}$ & $9,19 \pm 1,27^{\mathrm{c}}$ & $9,42 \pm 1,65^{\mathrm{c}}$ & $34,80 \pm 6,53^{\mathrm{c}}$ \\
\hline
\end{tabular}

Volume and concentration of C. macropomum and $P$. brachypomus, in this work, were lower than those found in the literature (RAMIREZMERLANO et al., 2011; VARELA JUNIOR et al., 2012). However, these parameters of $P$. brevis, in this work, were higher than those found in the literature (LOPES et al., 2014; SILVA et al., 2014). Reported differences may be related to induction hormonal (MARIA et al., 2010), diet, stage of maturation, environmental conditions (e.g., temperature, salinity, and photoperiod), ATP content, enzymatic activity, hormonal regulation of spermiation, secretory activity of the sperm duct, milt contamination, stress, or a combination of these factors (CIERESZKO, 2007). The osmolality found in this study is within pattern found in the literature for this species (260-313 mOms Kg-1) (LOPES et al., 2014; MARIA et al., 2010; NASCIMENTO et al., 2010).

With the advent of an automated method to evaluate motility (CASA), other aspects of spermatozoa movement have begun to be evaluated, such as curvilinear velocity (VCL), straight line velocity (VSL) e average path velocity (VAP), which are positively correlated with the fertilizing capacity of spermatozoa (VIVEIROS et al., 2010) as well as motility and the duration of motility (RANA, 1996).

The velocities follow the same pattern for the three species. There was a significant reduction in velocity (VCL, VSL e VAP) at $30 \mathrm{~s}$. This reduction was also significant at $60 \mathrm{~s}$. Thereafter, there was no significant reduction at $120 \mathrm{~s}$ post-activation. The $P$. brevis fish had higher velocities post-activation (10 s) with $131.59 \pm 6.64 \mu \mathrm{m} \mathrm{s}^{-1}$ (VCL), $113.81 \pm 5.97$ $\mu \mathrm{m} \mathrm{s}^{-1}$ (VAP) and $67.72 \pm 3.33 \mu \mathrm{m} \mathrm{s}^{-1}$ (VSL), while the $C$. macropomum fish had the lowest velocities $(10 \mathrm{~s})$ with $87.56 \pm 10.14 \mu \mathrm{m} \mathrm{s}^{-1}$ (VCL), $77.74 \pm$ $8.97 \mu \mathrm{m} \mathrm{s}^{-1}$ (VAP) and $52.49 \pm 6.20 \mu \mathrm{m} \mathrm{s}^{-1}$ (VSL) (Figure 1).

In the present study, the percentage of spermatozoa motility and spermatozoa velocity decreased as a function of time post-activation. The same phenomenon was observed in Cyprinus carpio (BORYSHPOLETS et al., 2009). For the three species observed in the present study, the percentage of motile cells remained similar until $30 \mathrm{~s}$; however, until $60 \mathrm{~s}$, there was a significant reduction in motility that was more accentuated at 120 s. In the $P$. brevis fish, despite the significant reduction at $120 \mathrm{~s}$, the motility was at $34.80 \%$, a reasonable value for use in fertilization programs (RAMIREZMERLANO et al., 2011; VARELA JUNIOR et al., 2012). Regarding the C. macropomum and $P$. brachypomus species, reasonable values are found at $60 \mathrm{~s}$ (35.74 and 33.68\%, respectively).

The differences found for each species may be related to ionic composition and osmolality of the seminal plasma, time of stripping during the reproductive season, and environmental factors regulating spermiation (i.e., temperature and photoperiod). Activation solution characteristics such as ion concentrations $\left(\mathrm{K}^{+}, \mathrm{Na}^{+}\right.$, and $\left.\mathrm{Ca}^{2+}\right)$, osmotic pressure, $\mathrm{pH}$, temperature and dilution rate affect motility (ALAVI; COSSON, 2006), which highlights the importance of the interaction of sperm with the activation solution. 
Spermatozoa activation leads to a decrease in the ATP content along with spermatozoa velocity and motility percentage decreases (BORYSHPOLETS et al., 2009). In addition, shorter duration of spermatozoa motility following activation in low hypo-osmolality conditions may be due to damage of the flagellum mediated by alterations in the spermatozoa plasma membrane (ALAVI et al., 2009). Additional studies related to the mechanisms of activation of Characiformes spermatozoa are needed for the understanding of various phenomena related to the quality of motility post-activation in artificial fertilization program.

Figure 1. VCL, VSL and VAP in $\mu \mathrm{m} \mathrm{s}^{-1}$ of P. brevis, C. macropomum and P. brachypomus species at 10, 30, 60 and 120 s post-activation. Velocities followed by different letters are significantly different at $\mathrm{p}<0.05$.
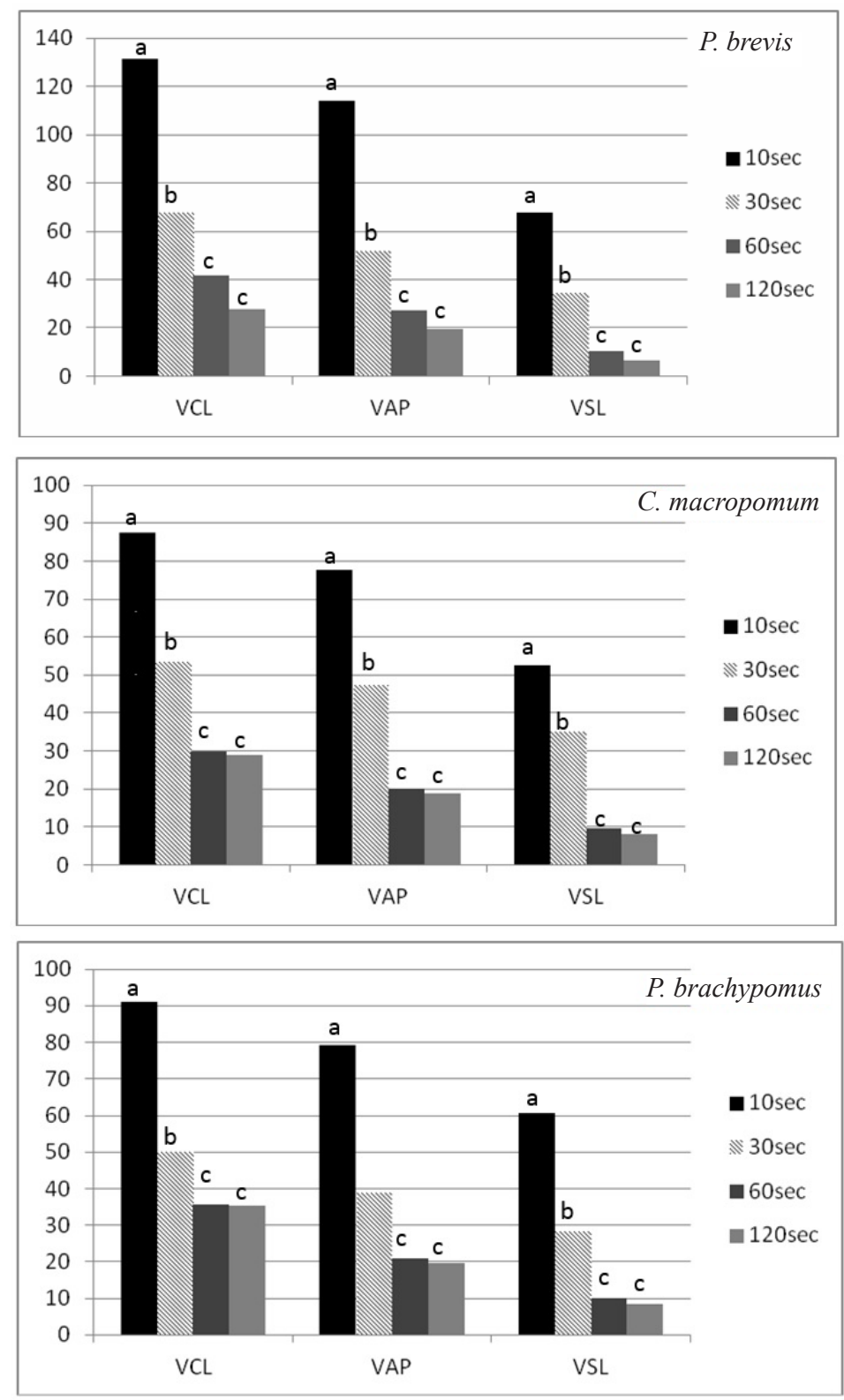
Sperm of C. macropomum and P. brachypomus show satisfactory sperm quality up to $60 \mathrm{~s}$ after activation. On the other hand, sperm of $P$. brevis up to $120 \mathrm{~s}$ after activation. These findings show that the rate of sperm motility in different times post activation is change for each species tested. Knowledge of seminal behavior is important to assist in the development and use of assisted reproductive protocols.

This study was supported by Departamento Nacional de Obras Contra as Secas (DNOCS) and Laboratório de Biotecnologia da Reprodução de Peixes (LBRP), for providing the facilities and the specimens used in the experiments. The Financiadora de Estudos e Projetos (FINEP) for financial support and Fundação Cearense de Apoio ao Desenvolvimento Científico e Tecnológico (FUNCAP) for granting the scholarship.

\section{References}

ALAVI, S. M. H.; COSSON, J. Sperm motility in fishes: (II) effects of ions and osmolality: a review. Cell Biology International, London, v. 30, n. 1, p. 1-14, 2006.

ALAVI, S. M. H.; RODINA, M.; VIVEIROS, A. T. M.; COSSON, J.; GELA, D.; BORYSHPOLETS, S.; LINHART, O. Effects of osmolality on sperm morphology, motility and flagellar wave parameters in Northern pike (Esox lucius L.). Theriogenology, New York, v. 72, n. 1, p. 32-43, 2009.

BORYSHPOLETS, S.; DZYUBA, B.; RODINA, M.; LI, P.; HULAK, M.; GELA, D.; LINHART, O. Freezethawing as the factor of spontaneous activation of spermatozoa motility in common carp (Cyprinus carpio L.). Cryobiology, Amsterdam, v. 59, n. 3, p. 291-296, 2009.

CARNEIRO, P. C. F. Tecnologias de produção e armazenamento de sêmen de peixes. Revista Brasileira de Reprodução Animal, Belo Horizonte, v. 31, n. 3, p. 361-366, 2007.

CIERESZKO, A. Chemical composition of seminal plasma and its physiological relationship with sperm motility, fertilizing capacity and cryopreservation success in fish. In: ALAVI, S. M. H.; COSSON, J.; COWARD, K.; RAFIEE, G. (Ed.). Fish spermatology. Oxford: Alpha Science International Ltd, 2007. p. 215-240.
COSSON, J. Frenetic activation of fish spermatozoa flagella entails short-term motility, portending their precocious decadence. Journal of Fish Biology, London, v. 76, n. 1, p. 240-279, 2010.

GODINHO, H. P.; VIVEIROS, A. T. M. Current status of sperm cryopreservation of brazilian characiform fishes. In: TIERSCH, T. R.; GREEN, C. C. (Ed.). Cryopreservation in Aquatic Species. $2^{\text {th }}$ ed. Baton Rouge: World Aquaculture Society, 2011. p. 875-884.

GURGEL, L. L.; VERANI, J. R.; CHELLAPPA, S. Reproductive ecology of Prochilodus brevis an endemic fish from the semiarid region of Brazil. The Scientific World Journal, New York, v. 2012, p. 1-7, 2012.

LOPES, J. T.; PINHEIRO, J. P. S.; NUNES, L. T.; PINHEIRO, R. R. R.; SOUZA, M. E. M.; ALMEIDA, P. S.; NASCIMENTO, R. V.; CAMPELLO, C. C.; SALMITO-VANDERLEY, C. S. B. Avaliação de diferentes crioprotetores e taxas de diluição na criopreservação seminal de Prochilodus brevis. Revista Brasileira de Reprodução Animal, Belo Horizonte, v. 38, n. 3, p. 170-175, 2014.

MARIA,A.N.;AZEVEDO, H. C.; SANTOS, J. P.; SILVA, C. A.; CARNEIRO, P. C. F. Semen characterization and sperm structure of the Amazon tambaqui Colossoma macropomum. Journal of Applied Ichthyology, Berlin, v. 26, n. 5, p. 779-783, 2010

NASCIMENTO, A. F.; MARIA, A. N.; PESSOA, N. O.; CARVALHO, M. A. M.; VIVEIROS, A. T. M. Outof-season sperm cryopreservation in different media of the Amazonian freshwater fish pirapitinga (Piaractus brachypomus). Animal Reproduction Science, Holanda, v. 118, n. 2-4, p. 324-329, 2010.

RAMIREZ-MERLANO, J. A.; VELASCOSANTAMARIA, Y. M.; MEDINA-ROBLES, V. M.; CRUZ-CASALLAS, P. E. Cryopreservation effects on the sperm quality of cachama blanca Piaractus brachypomus (Cuvier 1818). Aquaculture Research, Oxford v. 42, n. 6, p. 738-745, 2011.

RANA, K. J. Preservation of gametes. In: BROMAGE, N.; ROBERTS, R. J. Broodstock management and egg larval quality. Oxford: Blackwell Science, 1996. p. 5375.

SILVA, A. C.; GALVÃO, J. A. S.; TEIXEIRA, E. G.; FARIAS, W. R. L. Caracterização e resfriamento do sêmen de curimatã, Prochilodus brevis (Steindachnner, 1874). Revista Brasileira de Higiene e Sanidade Animal, Fortaleza, v. 8, n. 3, p. 105-129, 2014. 
VARELA JUNIOR, A. S.; CORCINI, C. D.; GHELLER, S. M. M.; JARDIM, R. D.; LUCIA JUNIOR, T.; STREIT JUNIOR, D. P.; FIGUEIREDO, M. R. C. Use of amides as cryoprotectants in extenders for frozen sperm of tambaqui, Colossoma macropomum. Theriogenology, New York, v. 78, n. 2, p. 244-251, 2012.
VIVEIROS, A. T. M.; NASCIMENTO, A. F.; ORFÃO, L. H.; ISAÚ, Z. A. Motility and fertility of the subtropical freshwater fish streaked prochilod (Prochilodus lineatus) sperm cryopreserved in powdered coconut water. Theriogenology, New York, v. 74, n. 4, p. 551-556, 2010. 
